\title{
The Response of Physical, Cognitive, Emotional in Patients with Mental Disorders Who Performed The Action Restraint
}

\author{
Yuniar Dewi ${ }^{1}$, Sawab ${ }^{1}$, Ramelan Sugijana ${ }^{1}$ \\ ${ }^{I}$ Nursing Department, Semarang Health Polytechnic \\ Corresponding author: niaratapsari@gmail.com
}

\begin{abstract}
Background: Handling is often done in mental hospitals is binding or restraint. Restraint is the act of someone using a rope bridle are made to control aggressive behavior arising from maladaptive response in the patient, control patients with severe mental disorders, prevent injuries, and reduce agitation and aggressive behavior.

Purpose: The study aims to describe the response of physical, cognitive, emotional in patients with mental disorders who performed the action restraint in UPIP Prof.Dr.Soerojo Magelang.

Methods: The study design was used descriptive explorative. Samples taken by total sampling as many as 51 patients. Research tool using a questionnaire responses of physical, cognitive, emotional in patients with mental disorders who do act restraint Data was analyzed by univariate. emotions on mental patients who do act restraint consisting of 6 physical response questions, 8 questions cognitive responses, and 7 questions emotional response.
\end{abstract}

Results: The results of this study with the respondent amounted to 51 patients showed early adult aged respondents were 19 patients (37.3\%), male sex were 51 patients $(100 \%)$, the majority of elementary education by 25 patients (49\%). Physical responses in patients with mental disorders who do restraint that is included in the heavy physical response by 36 patients $(70.6 \%)$, cognitive responses indicate cognitive responses were 28 patients $(54.9 \%)$, emotional responses indicate emotional responses were as many as 23 patients $(45.1 \%)$.

Conclusion: Patients with mental disorders are at high risk for behaving amuck which is a form of aggressive behavior, patient amok need more specialized treatment.

\section{Keywords:}

Mental Disorder; Action Restraint; Response

\section{LATAR BELAKANG}

Gangguan jiwa adalah suatu perubahan pada fungsi jiwa yang menyebabkan adanya gangguan pada fungsi jiwa yang menimbulkan penderitaan pada individu dan hambatan dalam melaksanakan peran sosial (Depkes RI,2010). World Health Organization (WHO) mengatakan bahwa $25 \%$ dari penduduk dunia pernah mengalami masalah kesehatan jiwa, $1 \%$ diantaranya merupakan gangguan jiwa berat. Jenis gangguan jiwa di Indonesia rata-rata gangguan jiwa berat seperti halusinasi, ilusi, waham, kemampuan berpikir, gangguan proses pikir serta tingkah laku yang aneh. Prevalensi terjadinya For complete information author guidelines please check 
gangguan jiwa berat di Indonesia berdasarkan Riset Kesehatan Dasar (2013) terdapat 1,7 orang permil yang mengalami gangguan jiwa. Kemugkinan gangguan jiwa akan bertambah populasi di tahun 2030. Pada tahun 2013 kejadian penderita gangguan jiwa di Jawa Tengah berkisar antara 2,3 permil (Riskesdas,2013).

Menurut data rekam medik Rumah Sakit Jiwa Prof. Dr. Soerojo Magelang pada tahun 2016 terdapat 3709 jiwa, pada tahun 2017 terdapat 3308 jiwa, dan pada tahun 2018 terhitung dari bulan Januari hingga Oktober terjadi penurunan yaitu 2841 jiwa. Sedangkan pasien gangguan jiwa yang dirawat di Unit Perawatan Intensif Psikiatri (UPIP) pada tahun 2016 terdapat 3568 jiwa, pada tahun 2017 terdapat 3202, sedangkan pada tahun 2018 terhitung sampai bulan Oktober terdapat 2694 jiwa

Pasien gangguan jiwa beresiko tinggi untuk berperilaku amuk yang merupakan bentuk dari perilaku agresif. Perilaku agresif adalah bentuk perilaku yang bertujuan untuk melukai orang lain secara fisik maupun psikologis. Pasien amuk perlu penanganan lebih khusus dibanding dengan pasien gangguan jiwa yang keadaanya tenang. Penatalaksanaa pasien gangguan jiwa di Unit Perawatan Intensif Psikiatri (UPIP) adalah salah satunya dengan pemberian tindakan restraint.

Menurut data rekam medik Rumah Sakit Jiwa Prof. Dr. Soerojo Magelang pada tahun 2017 terdapat 497 jiwa, pada tahun 2018 terhitung dari bulan Januari hingga Oktober terdapat 510 pasien yang diberikan tindakan restraint. Restraint adalah tindakan yang dilakukan untuk mengendalikan perilaku agresif yang timbul akibat respon maladaptif dalam diri pasien, mengontrol pasien dengan gangguan mental yang berat, mencegah cidera, dan mengurangi agitasi serta perilaku yang agresif (Moghadam, Khoshknab dan Pazargadi 2014). Pravalensi tindakan restrain yang dilakukan di Rumah Sakit berkisar antara 8\% sampai 68\% (Hamers, Huizing,2005 dalam Scheepmanset al 2014).

Restrain biasanya dilakukan pada pasien gangguan jiwa yang membahayakan diri dan orang lain, perilaku agitasi yang sulit dikendalikan dengan pengobatan, ancaman terhadap integritas fisik yang berhubungan dengan penolakan pasien untuk istirahat, makan, dan minum, serta permintaan pasien untuk pengendalian perilaku eksternal (Sulistyowati,2014).

Tindakan restrain jika dilakukan dengan tidak benar akan menyebabkan cedera fisiologis dan psikologis. Dampak yang dapat ditimbulkan dari tindakan retraint adalah dapat menimbulkan luka secara fisik perasaan negatif pada diri pasien serta anggota keluarganya, pengalaman distress secara psikologis, memicu tindakan penyerangan, merusak hubungan terapeutik antara pasien dan tenaga kesehatan. Sementara itu dampak dari tenaga kerja seperti memicu timbulnya luka secara fisik, dampak secara emosional, dan menyebabkan kematian (Pollardet al, 2007).

Perlu dilakukan penelitian tentang gambaran respon fisik, kognitif, emosi pada pasien gangguan jiwa yang dilakukan tindakan restrain di Ruang UPIP Rumah Sakit Jiwa Prof. Dr. Soerojo Magelang. 


\section{TUJUAN}

Penelitian ini bertujuan untuk mengetahui gambaran respon fisik, kognitif, emosi pada pasien gangguan jiwa yang dilakukan tindakan restraint di Ruang UPIP Prof.Dr.Soerojo Magelang

\section{METODE}

Desain penelitian adalah model yang dapat digunakan peneliti sebagai petunjuk dalam perencanaan dan pelaksanaan penelitian untuk mencapai suatu tujuan atau menjawab suatu pertanyaan penelitian (Nursalam, 2013). Penelitian ini menggunakan metode penelitian deskriptif eksploratif yang bertujuan untuk menggambarkan suatu keadaan suatu fenomena, di dalam penelitian ini tidak menguji hipotesis tertentu tetapi hanya menggambarkan respon fisik, kognitif dan emosi pada pasien gangguan jiwa yang dilakukan tindakan restrain.

Penelitian dilakukan di Ruang UPIP Rumah Sakit Jiwa Prof. Dr. Soerojo Magelang pada bulan Desember sampai dengan Febuari 2019 dengan jumlah responden 51 orang. Dengan kriteria inklusi sebagai berikut: Klien yang berperilaku agresif dan mendapatkan skor RUFA intensif 1 (skor 1-10), Klien dengan tingkat kesadaran composmentis, Klien dengan tindakan restrain tali. Kriteria ekslusi sebagai berikut: Klien yang di restraint setelah mendapatkan terapi ECT (electroconvulsive therapy).

Instrument yang digunakan yaitu informed consent, Skor Rufa, kuesioner respon fisik yang terdiri dari 6 pertanyaan respon fisik, respon kognitif yang terdiri dari 8 pertanyaan, respon emosi terdiri dari 7 pertanyaan dan observasi fisik. Data dianalisis secara univariat.

\section{HASIL}

Responden penelitian ini adalah semua pasien gangguan jiwa . Variabel independen penelitian ini yaitu tindakan restraint, sedangkan variabel dependennya adalah respon fisik, kognitif, emosi. Responden pada penelitian ini terdiri dari 51 responden.

Tabel 1 Karakteristik Responden Berdasarkan usia pasien gangguan jiwa yang dilakukan restraint $(n=51)$

\begin{tabular}{lccc}
\hline \multicolumn{1}{c}{ Variabel } & $\begin{array}{c}\text { Rentang } \\
\text { usia (tahun) }\end{array}$ & Frekuensi & $\begin{array}{c}\text { Persentase } \\
(\%)\end{array}$ \\
\hline Remaja awal & $12-16$ & 3 & 5,9 \\
Remaja akhir & $17-25$ & 8 & 15,7 \\
Dewasa awal & $26-35$ & 19 & 37,3 \\
Dewasa akhir & $36-45$ & 12 & 23,5 \\
Usia pertengahan (middle age) & $46-59$ & 3 & 5,9 \\
Lansia (elderly) & $\geq 60$ & 6 & 11,8 \\
\hline
\end{tabular}

For complete information author guidelines please check 
Berdasarkan tabel 1, didapatkan rata-rata usia sebagian besar responden dalam penelitian ini berada pada rentang usia dewasa awal yaitu dengan jumlah 19 orang $(37,3 \%)$.

Tabel 2 Karakteristik Responden Berdasarkan jenis kelamin pasien gangguan jiwa yang dilakukan resraint $(\mathrm{n}=51)$

\begin{tabular}{ccc}
\hline Variabel & Frekuensi & Persentase (\%) \\
\hline Laki-laki & 51 & 100 \\
Tidak sekolah & 2 & 3,9 \\
SD & 25 & 49 \\
SMP & 18 & 35,3 \\
SMA & 6 & 11,8 \\
\hline
\end{tabular}

Berdasarkan tabel 2, didapatkan hasil bahwa responden pada penelitian ini berdasarkan jenis kelamin pasien gangguan jiwa yang dilakukan tindakan restraint menunjukkan bahwa semua responden berjenis kelamin laki-laki dengan frekuensi 51 orang (100\%). Responden berdasarkan tingkat pendidikan pasien gangguan jiwa yang dilakukan tindakan restraint menunjukkan bahwa sebagian besar responden berpendidikan SD yaitu 25 orang (49\%) dari total responden sebanyak 51 orang.

Tabel 3 Karakteristik Responden Berdasarkan tingkat pekerjaan pasien gangguan jiwa yang dilakukan resraint $(\mathrm{n}=51)$

\begin{tabular}{ccc}
\hline Variabel & Frekuensi & Persentase (\%) \\
\hline Tidak Bekerja & 31 & 60,8 \\
Petani & 7 & 13,7 \\
Swasta & 6 & 11,8 \\
Supir & 1 & 2 \\
Buruh & 3 & 5,9 \\
Nelayan & 1 & 2 \\
Pensiunan & 2 & 3,9 \\
\hline
\end{tabular}

Berdasarkan tabel 3, didapatkan responden berdasarkan tingkat pekerjaan pasien gangguan jiwa yang dilakukan tindakan restraint menunjukkan bahwa sebagian besar responden berstatu tidak bekerja yaitu 31 orang $(60,8 \%)$ dari total responden sebanyak 51 orang

Tabel 4 Respon fisik responden pada saat dilakukan tindakan restraint

\begin{tabular}{ccc}
\hline Variabel & Frekuensi & Persentase $(\%)$ \\
\hline Respon fisik ringan & 2 & 3,9 \\
Respon fisik sedang & 13 & 25,5 \\
Respon fisik berat & 36 & 70,6 \\
\hline
\end{tabular}

For complete information author guidelines please check 
Berdasarkan tabel 4, didapatkan responden berdasarkan kategori respon fisik ringan, respon fisik sedang, dan respon fisik berat pada pasien gangguan jiwa yang dilakukan restraint didapatkan hasil yaitu sebagian besar responden masuk dalam respon fisik berat yaitu sebesar $36(70,6 \%)$ responden dari total responden sebanyak 51 orang

Tabel 5 Respon kognitif responden pada saat dilakukan tindakan restraiint

\begin{tabular}{ccc}
\hline Variabel & Frekuensi & Persentase (\%) \\
\hline Respon kognitif ringan & 9 & 17,6 \\
Respon kognitif sedang & 28 & 54,9 \\
Respon kognitif berat & 14 & 27,5 \\
\hline
\end{tabular}

Berdasarkan tabel 5, didapatkan responden berdasarkan kategori respon kognitif ringan, respon kognitif sedang, dan respon kognitif berat pada pasien gangguan jiwa yang dilakukan restraint didapatkan hasil yaitu sebagian besar responden masuk dalam respon kognitif sedang yaitu sebesar $28(54,9 \%)$ responden dari total responden 51 orang

Tabel 6 Respon emosi responden pada saat dilakukan tindakan restraint

\begin{tabular}{ccc}
\hline Variabel & Frekuensi & Persentase (\%) \\
\hline Respon emosi ringan & 14 & 27,5 \\
Respon emosi sedang & 23 & 45,1 \\
Respon emosi berat & 14 & 27,5 \\
\hline
\end{tabular}

Berdasarkan tabel 6, didapatkan responden berdasarkan kategori respon emosi ringan, respon emosi sedang, dan respon emosi berat pada pasien gangguan jiwa yang dilakukan restraint didapatkan hasil yaitu sebagian besar responden masuk dalam respon emosi sedang yaitu sebesar $23(45,1)$ responden dari total responden 51 orang

Tabel 7 Observasi kelainan fisik responden pada saat dilakukan tindakan restraint

\begin{tabular}{ccc}
\hline Variabel & Frekuensi & Persentase $(\%)$ \\
\hline Observasi kelainan fisik ringan & 37 & 72,5 \\
Observasi kelainan fisik sedang & 11 & 21,6 \\
Observasi kelainan fisik berat & 3 & 5,9
\end{tabular}

Berdasarkan tabel 7, didapatkan responden berdasarkan kategori observasi kelainan fisik ringan, observasi kelainan fisik sedang, dan observasi kelainan fisik berat pada pasien gangguan jiwa yang dilakukan restraint didapatkan hasil yaitu sebagian besar responden masuk dalam observasi kelainan fisik sedang yaitu sebesar $37(72,5)$ responden dari total responden 51 orang. 


\section{PEMBAHASAN}

Hasil penelitian ini menunjukkan bahwa sebagian besar responden berjenis kelamin laki-laki sebesar 51 responden $(100 \%)$ hal ini sesuai dengan sebanding dengan penelitian (Sujarwo, 2017) dan (Soewadi, 2009) sehingga hasil penelitian sekarang dan sebelumnya dapat dikemukakan bahwa jenis kelamin juga sangat berpengaruh dalam pasien gangguan jiwa yang menunjukkan bahwa laki-laki yang lebih banyak mengalami gangguan jiwa karena pengaruh lingkungan, hubungan sosial, kebiasaan dalam kehidupan sehari-hari tersebut dapat memicu terjadinya gangguan jiwa.

Tingkat umur tertinggi pada penelitian ini yaitu pada rentang dewasa awal dengan jumlah sebesar 19 responden $(37,3 \%)$ hal ini sesuai dengan pernytaan (Ardiyanti,2014) yang menyatakan bahwa kejadian kegawatdaruratan jiwa pada individu berusia 25-45 tahun lebih tinggi dibanding usia kurang dari 25 atau lebih dari 45 tahun.

Tingkat pendidikan pada penelitian ini menunjukan pendidikan tertinggi responden berada pada tingkat SD yaitu sebanyak 25 responden (49\%) \%. Hal ini sesuai dengan penelitian yang telah dilakukan oleh (Kirana, 2014) yang telah mengatakan bahwa tingkat pendidikan rendah pada seseorang akan menyebabkan cara berpikir rasional, menangkap informasi yang baru, dan kemampuan menyelesaikan masalah menjadi rendah.

Gambaran respon fisik akibat dilakukannya tindakan restraint pada pasien gangguan jiwa pada penelitian ini menunjukkan bahwa tertinggi respon fisik berat yaitu sebanyak 36 responden $(70,6 \%)$ dengan ditemukannya pasien yang merasa kesakitan pada anggota gerak, merasa kesulitan bergerak, merasa kesulitan makan dan minum, merasa tidak dapat makan dan minum dan tidak dapat BAB/BAK saat terpasang tali. Rotondi (2010) mengatakan bahwa respon fisik timbul karena ketidaknyamanan fisik pasien saat dilakukan tindakan restraint hal ini terjadi karena pasien gangguan jiwa mempengaruhi individu dalam berinteraksi dengan orang lain dan lingkungan, merasa tidak dapat $\mathrm{BAB} / \mathrm{BAK}$ secara mandiri karena restraint secara umum mengacu pada suatu bentuk tindakan menggunakan tali untuk mengekang individu yang berperilaku diluar kendali. Pasien yang mengalami kegawatdaruratan lebih banyak yang mengalami respon fisik berat Sujarwo (2017)

Gambaran respon kognitif akibat dilakukannya tindakan restraint pada pasien gangguan jiwa pada penelitian ini menunjukkan bahwa tertinggi respon kognitif sedang yaitu sebanyak 28 responden $(54,9 \%)$ dengan ditemukannya pasien merasa bahwa di pasang tali merupakan suatu bentuk hukuman baginya, merasa tidak aman saat dipasang tali, merasa dikekang saat dipasang tali, merasa takut akan mengalami kecacatan dan merasa tindakan pengekangan tali tidak perlu dilakukan Theodore (2009) berpendapat bahwa pada pasien gangguan jiwa yang dilakukan tindakan restraint akan berdampak pada kognitifnya dan pasien menganggap bahwa pengekangan tersebut sebagai hukuman bagi dirinya, muncul kecemasan pada diri pasien, rasa marah dan takut. 
Gambaran respon emosi akibat dilakukannya tindakan restraint pada pasien gangguan jiwa pada penelitian ini menunjukkan bahwa tertinggi pada respon emosi sedang yaitu sebanyak 23 responden $(45,1 \%)$ dengan ditemukannya pasien yang merasa tidak dihargai hak asasinya, merasa sedih saat dipasang tali, merasa ingin mati, merasa keinginan untuk marah meningkat. Pada penelitian ini sesuai dengan pernyataan Edna (2009) yang mengatakan bahwa pasien gangguan jiwa yang dilakukan tindakan restraint akan mengalami dampak emosional pada psikologisnya yaitu berkurangnya kualitas hidup, depresi, peningkatan perilaku agresif. Restraint dapat menyebabkan klien merasa tidak dihargai hak asasinya sebagai manusia, untuk mencegah perasaan tersebut perawat harus mengidentifikasi faktor pencetus apakah sesuai indikasi dan untuk intervensi yang paling akhir apabila intervensi lain gagal mengatasi perilaku klien (Purwanto, T., dkk, 2009).

\section{SIMPULAN}

Dalam penelitian ini didapatkan gambaran respon fisik pada pasien gangguan jiwa yang dilakukan tindakan restraint dengan hasil respon fisik berat yaitu sebanyak 36 responden (70,6\%). Respon kognitif pada pasien gangguan jiwa yang dilakukan tindakan restraint dengan hasil respon kognitif sedang yaitu 28 responden (54,9\%). Respon emosi pada pasien gangguan jiwa yang dilakukan tindakan restraint dengan hasil respon emosi respon emosi sedang yaitu sebanyak 23 responden $(45,1 \%)$.

\section{REFERENSI}

Ardiyanti, D.M. 2016. Kategori pasien gangguan jiwa berdasarkan triage di instalasi gawat darurat rumah sakit jiwa daerah surakarta. Doctoral dissertation. Universitas Muhammadiyah Surakarta.

Depkes RI. 2010. Pengertian Gangguan Jiwa. Diakses pada tanggal 10 Oktober 2018 dari http://www.depkes.co.id.

Purwanto, T. 2009. Asuhan Keperawatan Jiwa. Yogyakarta: Graha Ilmu.

Riset Kesehatan Dasar(Riskesdas). 2013. Badan Penelitian dan Pengembangan Kesehatan Kementerian RI tahun 2013.Diakses: 19 Oktober 2014, dari http://www.depkes.go.id/resources/download/general/Hasil\%20Riskesdas $\% 20$ 2013.pdf.

Rotondi AJ, Chelluri L, Sirio C, Mendelsohn A, Schulz R, Belle S, et al. 2010 Patients' recollections of stressful experiences while receiving prolonged mechanical ventilation in an Intensive Care Unit. Crit Care Med hal:74652.

Soewadi. 2009. Manajemen Keperawatan dengan Pendekatan Praktis. Jaka Erlangga. Sujarwo. 2017. Gambaran Dampak Tindakan Restrain Pasien Gangguan Jiwa. Jurnal Ilmiah, 37-44. 